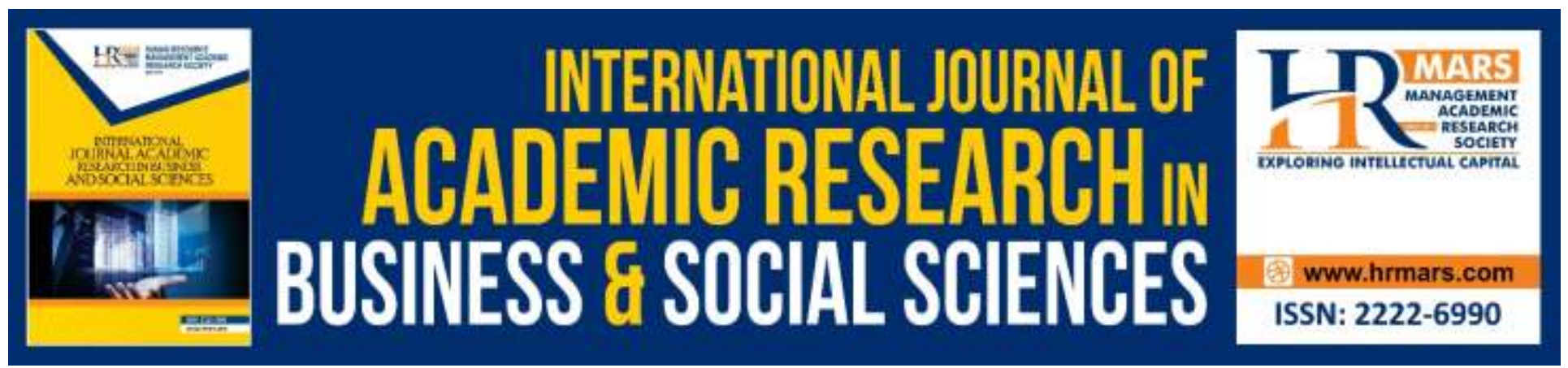

\title{
The Relationship between Compensation Strategy and Employee Performance among Academic Staff in Iraqi Universities: A Literature Review
}

Firas Salman Khudhair, Rafiduraidabinti Abdul Rahman and Ahmad Amri Bin Zainal Adnan

To Link this Article: http://dx.doi.org/10.6007/IJARBSS/v10-i1/6848

DOI:10.6007/IJARBSS/v10-i1/6848

Received: 21 December 2019, Revised: 03 January 2020, Accepted: 18 January 2020

Published Online: 30 January 2020

In-Text Citation: (Khudhair et al., 2020)

To Cite this Article: Khudhair, F. S., Rahman, R. A., \& Adnan, A. A. B. Z. (2020). The Relationship between Compensation Strategy and Employee Performance among Academic Staff in Iraqi Universities: A Literature Review. International Journal of Academic Research in Business and Social Sciences, 10(1), 251-263.

Copyright: (c) 2020 The Author(s)

Published by Human Resource Management Academic Research Society (www.hrmars.com)

This article is published under the Creative Commons Attribution (CC BY 4.0) license. Anyone may reproduce, distribute, translate and create derivative works of this article (for both commercial and non-commercial purposes), subject to full attribution to the original publication and authors. The full terms of this license may be seen

at: http://creativecommons.org/licences/by/4.0/legalcode

Vol. 10, No. 1, 2020, Pg. 251 - 263

http://hrmars.com/index.php/pages/detail/IJARBSS

JOURNAL HOMEPAGE

Full Terms \& Conditions of access and use can be found at http://hrmars.com/index.php/pages/detail/publication-ethics 


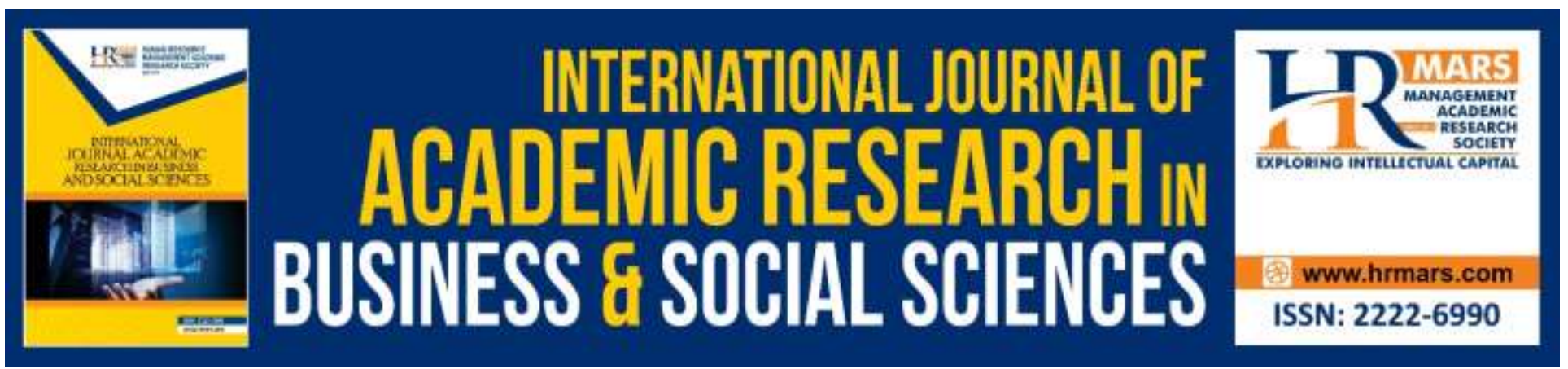

\title{
The Relationship between Compensation Strategy and Employee Performance among Academic Staff in Iraqi Universities: A Literature Review
}

\author{
Firas Salman Khudhair, Rafiduraidabinti Abdul Rahman and Ahmad \\ Amri Bin Zainal Adnan \\ University Pendidikan Sultan Idris (UPSI), Perak DarulRidzuan, Malaysia \\ Email: firas1990salman19@gmail.com,Rafiduraida@fpe.upsi.edu.my, a.amri@upsi.edu.my
}

\begin{abstract}
This paper aims to explore the past studies that investigate the connection concerning the compensation strategy and performance of the employee in various countries. Specifically, this study revolves around the Iraqi universities to obtain similar objective as the past studies. This paper is based on secondary sources, which are accumulated from many types of research in the USA, Canada, the UK, Indonesia, European, Nigerian, Japanese, China, Pakistan, Saudi Arabia, and Jordan. The study uses information that had been accumulated during the review of various literature to address the topic. Regression analysis documents are significant evidence to support an affirmative connection between the compensation strategy and the performance of the employee. The evidence revealed that compensation strategy leads to the increment of employee's performance in Iraqi universities. This outcome indicated that there is a positive connection between the compensation strategy and the performance of the employee. As this study intentionally focuses on the connection concerning the compensation strategy and the performance of the employee in Iraqi universities, therefore, the outcome of this study will significantly assist the universities to enhance their ability to meet the challenges of the current and future competition. The study will also provide several important insights to strengthen the understanding of compensation strategy in developing economies and their impacts on the performance of the employee in the setting of Iraqi universities.
\end{abstract}

\section{Introduction}

Compensation is a type of remuneration that can psychologically encourage the employee to focus and perform better with their jobs. David (2002); Dremina et al., (2016) asserted that the employee's turnover occurs due to a lack of appropriate compensation. Stewart et al. (2001) opined that compensation is referring to various types of rewards attained by the employee for their outstanding progress of the task given. Compensation is immensely vital for an organization. Failure to establish a promising compensation system can lead to negative impacts on the productivity, the employee's 
job satisfaction level, and also the overall reputation and performance of the firm (Negash et al., 2014). Therefore, the employees' performance can be enhanced by applying compensation strategies (McOliver, 2005). Nonetheless, organizations that fail to allow the employee to be involved in the process of making a decision can hinder their performance. Additionally, an organization that fails to implement and formulate rational decisions on the issues related to institutions hamper employee performance (Han et al., 2010; Yamoah, 2013).

Compensation consists of two main components; financial compensation and non-financial compensation. Financial compensation involves monetary incentives, which an employee achieved due to his excellent performance at work. On the other hand, non-financial compensations comprise of career development, job design, training and participation, working environment, and recognition (Baeten, 2010; Spaans, 2010; Prasetya \& Kato, 2011). In the Iraqi universities, several problems had been confronted by the employees, which can also affect the overall performance of Iraqi universities. Most of the problems were related specifically to the matter of increment in pay. Most employees feel the injustice in the pay system with the university's pay structure as the employees, who belong to other universities, are earning bigger pay than them (Al-Ameryeen, 2015) and eventually created dissatisfaction among the employees. Therefore, this research aims to provide greater insights on how the employees in Iraqi universities will be motivated to improve their performance as well as to enhance the level of performance in Iraqi universities.

According to Hameed and Waheed (2011), an employee is the most crucial element of an organization as the success of it depends on the employees' performance. To develop the employee's performance, the majority of the resources of an organization are used. The performance is an idea depicting how a man can utilize his particular potential or genuine information, skills, and capacities with a specific end goal to achieve the objectives or desires.

\section{Literature Review}

\section{Compensation Strategy}

According to Moghimi et al. (2017), compensation strategy should be able to ensure the retention of the employee, employee's satisfaction, the development as well as performance the employee. General findings showed that it possesses positive notable connections among incentive allowances, bonuses, fringe benefits, and salary. In brief, there is a co-bonding between these variables, which undoubtedly consider performance as a connection among the compensation benefit schemes, levels of employee contentment, and turnover rate. This concluded that organizations with upgraded compensation system may have an impact on their employees. This will psychologically encourage them to be in the organizations (Wucher et al., 2017). Linking "compensation to performance" is one of the strategies being followed all over the world in all sectors for talent management and employee retention. Generally, it is called "Pay for Performance" or "Performance-based pay" to describe that compensation depends on the performance of the employees and their contributions to attain the organizational goals (Tima, 2011).

The vigorous relationship between the compensation elements schemes leads to a strong assumption of employee retention (Adeoye \& Fileds, 2014). Compensation strategy needs to have upgrade frameworks that can motivate, retain, attract, and satisfy the employees and thus leads to employee retention and satisfaction. According to George et al. (2016), this motivates the best 
performers to be more enthusiastic and can also prepare them to be more competitive within the organization. Furthermore, Nchorbuno (2011) opined that a pure integral section of HRM is the compensation that assists and inspires the employees as well as to develop the organizational effectiveness to a certain extent. Thus, the connection between compensation and work performance can be assured, as stated by Quartey and Attiogbe (2013). The dealing of compensation should be implemented to every sort of achievement the employees had received such as accomplishing organizational tasks with an expected outcome of the individuals who are thoroughly interacted with the work, contented, and inspired to perform a better performance for the employer (Premalatha 2013; George et al., 2016).

Njoroge and Kwasira (2015) discovered a major association concerning the strategies of the compensation and the performance of the employee. For example, MaysounBaqer Mahdi (2015) elaborated that an organization can attract, motivate, and retain their employees by offering competitive salaries and suitable rewards based on their performance and development in the organization. Furthermore, Inés and Pedro (2015) further mentioned that the compensation system is applied to bring out its significant effects on the employees' performance. Today, many organizations around the world are trying to discover an innovative compensation strategy that can enhance the performance of the employee directly (Denis \& Michel, 2011).

\section{Employee Performance}

Various explanations associated with the term 'performance' had been presented in past studies. According to Hellriegel et al. (1999), performance is referred to as the level of an individual's achievement after pouring great effort along with the assistance of the environmental variable. It is part of the HR practices to determine the employee's progress in the organization (Campbell, McCloy, Oppler \& Sager, 1993). Based on the outcome of this practice, it acts as the framework in determining the status of the educational organizations and to measure its competitive advantage among other organizations. Thus, it is crucial to measure the performance of the employees in every institution. Pradhan and Jena (2017) highlighted that the main factors to measure the performance are by evaluating the employee's performance in completing the task, adaptive performance, and contextual performance. These factors are believed to be the most influencing attributes to measure the performance level.

Nevertheless, several organizations only focus on satisfying the customers and tend to neglect the attention in satisfying their employees. In reality, customer's satisfaction can be attained if the employees are satisfied. According to Ahmad (2011), a satisfied employee will always do more work and therefore, makes it easy to satisfy the customer. Besides, motivation can also influence an employee's performance. For instance, if employees are motivated and satisfied with the compensation offered, they will perform with full commitment and as a result, the performance level will significantly improve (Shahzadi et al., 2014). Several components are vital as employee's performance determines the success and performance of the organization. By sharing and combining the endeavour of all the employees, organizational performance can be measured. Anwar et al. (2011) asserted that performance is the key factor in attaining the organizational goal due to the vital connection with the intended purposes of the organization. To reach the organizational success mark and purposes, the leaders and the employees of any level must contribute their energy through their 
performance and build the utmost utilization of their abilities. Based on the performance of the leaders and employees, the organizations will have several expectations. Therefore, in many circumstances, employees will try to accomplish these expectations. In some cases, they tend to rely on their bosses or in their management. Therefore, the employees should be compensated strategically by demonstrating committed performance to fulfil their tasks and responsibilities artistically (Anitha, 2014).

However, employees believed that their performance is highly influenced based on the nature of the work, compensation strategy, and also the promotion opportunities among the organizations. Therefore, organizations should concentrate on their fair promotions and compensations system as fair promotion and compensations can motivate the employees to perform consistently. Boamah (2014) opined that work appraisal, salary, work environment, and the relationship between the manager and employees tend to bring significant effects on the performance of the employee.

\section{Relationship between Compensation Strategy and Employee Performance}

According to Tinaikar (2017), many past studies had revealed similar outcomes proving that there is a strong connection between the compensation strategy and the performance and retention of the employee. Ramanathan (2012) reported the existence of a positive relationship concerning the compensation and how well the employees performed in their task due to the existence of bonuses and employee ownership. Similarly, a significant relationship between compensation and employee performance was also found by several researchers such as Tima and AK (2011), Ramanathan (2012), and Shiah-Hou and Cheng (2012). They opined that by offering competitive salaries and appropriate rewards to the employee, the employee will improve their work performance and the growth of the employees in the organization can be developed due to the capability of the company to attract, inspire, and retain the employees in the organization. Besides, Kuster and Canales (2011) discovered that the enhancement of the employees' performance and the effectiveness of the organization can be attained when the organization utilizes an effective compensation system. However, TettehAnnor (2014) highlighted the consequence of the current business environment and opined that it is too competitive. Therefore, several organizations are trying to discover compensation strategies that can be innovative in improving the performance of the employees.

Consequently, periodic performance reviews play a significant role to provide the basis of performance-related pay. Although there are other factors without compensation, compensation is considered as a major factor that can lead to the employee's performance improvement (Mabaso \& Dlamini, 2017). If the employee is admired by the organization for their effort and offered a compensation system with positive job evaluation, it will psychologically enhance the employees' motivation and enthusiasm (Premalatha, 2013; Tetteh-Annor, 2014).

Nevertheless, Rizal et al. (2014) found that offering competitive salaries and appropriate rewards can enhance the organization's performance and growth as it can attract, motivate, and retain the employees in the organization. Likewise, Alfandi and Alkahsawneh (2014) had also discovered that the performance of the employee and the effectiveness of the organization are significantly relying on the compensation system used for the employee. It has proven that the compensation strategy has a vital role in enhancing employees' performance. June and Mahmood (2011) and Jean et al., (2017) had depicted the present scenario by denoting the current competitive 
business environment by many institutions and therefore, urging the organizations to find other rewarding techniques to improve the employee's performance.

In contrast, Shin-Rong and Chin-Wei (2012) had discovered that there is a huge gap between compensation and employee. Similar to the findings by Mayson and Barret (2006), the efforts are done by an institution to attract, spur, and retain employees through the offering of competitive pay rates and suitable rewards are significantly connected to the performance of the institution. On the other hand, Denis and Michel (2011) opined that along these lines, in a competitive business condition, numerous institutions today are endeavouring to recognize creative compensation strategies that are specifically connected to enhance further in the future. However, customers' fulfilment and performance of the institutions are the consequence of their worker's accomplishment (Hausman et al., 2002). There have been researches demonstrating an affirmative connection between stock reward and worker performance. As propounded by Collins and Clark (2003), pay based on the performance is the prevailing human resource practice that most organizations generally assess. Besides, pay based on performance has a beneficial outcome on the worker and authoritative's performance (Barringer et al., 2005). Results showed that motivating forces of employed individuals had separated the rapidly developing organization from the moderate developing organization. Institutions that are arranged with as rapid development tend to give their workers financial impetuses and investment opportunities as a major aspect of their pay bundles. Consequently, the organization able to figure out how to evoke the top-notch categories of performance from employed individuals, give the workers the inclination that they have as an ownership enthusiasm for the institution, attract, and hold the astounding workers.

Sudiardhita et al. (2018) had conducted a study using exploratory research method and respondents of the study were employees. The results of this study indicated that compensation has a positive and significant impact on the employee's work motivation, job satisfaction, and performance. Besides, Jean et al. (2017) conducted a case study was to discover the effect of compensation strategies on employee performance in Mombasa Cement Limited. Questionnaires were used as the primary research instrument to collect the data from the selected respondents. The result revealed that compensation has a significant effect on job satisfaction and employee performance. Meanwhile, Hameed et al. (2014); Peprah, (2018). Azman, Shuraimi, Binti \& Yunus (2018) conducted quantitative research to collect the data on the factors related to compensation such as salary, rewards, compensation, and employee performance. Their outcome also revealed that compensation has a major influence on the performance of the employee.

Masea (2016) has conducted a study by applying the quantitative research method. The study utilized questionnaires as the primary research instrument for data collection from the respondents, who are the academic staff in higher education institutions in South Africa. It was discovered that compensation has a positive impact on the performance of the employee. A similar outcome was reported by Ramli (2019) who also utilized the quantitative research method in his study. The respondents who were involved in the study were the employees of RumahSakitSwasta in Jakarta. The outcome also demonstrated a similar finding whereby the compensation has a significant effect on job satisfaction and the employee's performance. Haryono (2019) asserted that compensation is the organizations' obligation that must be conducted as a form of appreciation for the progress made by the employees to the organization. The organization should respect and acknowledge all the 
efforts made by the employees by giving them reasonable compensation based on the tasks they had performed. Thus, compensation does affect the level of performance done by the employee. In general, good performance and efficient outcomes are highly demanded in the current globalization era. Therefore, many organizations are implementing the compensation system. It is believed that effective compensation is predictable to add value to the employee's satisfaction, which can psychologically encourage the employees to perform effectively and efficiently.

Another study that was conducted using a quantitative research method was done by Darma and Supriyanto (2017). The study was conducted to determine the impact of the compensation variable on the employee performance variable. The compensations were in the form of allowances, bonuses, salaries, and wages. Indeed, these compensations do have a significant impact on the employee's progress towards work completion. Nwokocha (2016) applied the compensation strategy in organizations to ascertain their efficacy on the performance of the employees, retention, and level of productivity. This study had revealed that there is a positive connection between compensation and the performance of the employees' performance, retention, and productivity in the organization. Based on this outcome, the compensation system with articulated strategies should be embedded in the organization's culture. The management should also recognize and understand the employees' needs/preferences in establishing the compensation structure of the organizations. The use of these notions matched to a good managerial disposition, which will allow the organizations to formulate effective and sustainable strategies that will acknowledge the fair and sufficient reward for employees. This will improve the performance and the progress of the employees, retention, and productivity in the organization.

Another study was conducted by Demerouti et al. (2014) to investigate the compensation model with the strategies in the selective optimization. Based on a few samples of employees, they discovered that the appropriate technique to hinder the negative impacts on the employee's performance. This study had revealed the effective and ineffective techniques that people use to overcome their burnout symptoms to attain maximum outcomes on the performance of the employees. Besides, a study by Ibrar and Khan (2015) had similarly discovered that the employee's performance can be improved with the implementation of an effective compensation system in the organization. Questionnaires were used as the instrument of the study to conduct the descriptive analysis, correlation, and multiple regression tests for the data analysis. Overall, based on the analysis, the study had concluded that there is a significant connection between the compensation strategy and the performances of the employee.

Larbi's (2014) study discovered that there is a significant connection between the overall compensation, the management, and the performance of employees. In certain circumstances, the employee will not have a clear picture of their rights when it is related to the matter of compensation. This situation can be perceived due to the employers are not exposing the employees to the clause regarding compensation or the employees are not interested to read the policy manuals when they are provided with the manual. Thus, the management of the organization must ensure that the employees are aware of the policies related to the matter of the compensation system and the rewards offered. Other studies done by Brown et al. (2003), Obasan (2012), Lawler and Worley (2016), and Okeke and Ikechukwu (2019) had also discovered similar outcome that there is a significant connection between the compensation system and the employee's performance in an 
organization. Salaries, rewards, allowance, and non-financial compensations bring a major impact on the performance of the employee in the organizations. Therefore, based on the outcomes of several past studies, it can be concluded that compensation has a positive impact on the employee's progress and performance in many organizations.

However, there have been debates among scholars relating to the type and blend of compensation methods that are best for the institutions. A few studies have exhibited that rewards have positive impacts on the workers' development and progress as well as workplace security. It is one of the elements that will be highlighted to increase the employee's commitment to task completion (Furtado, 2015; Lawler \& Worley, 2016).

\section{Conclusion}

The main aim of this paper is to comprehensively review the connection between the compensation strategy and its impact on the employee's performance (EP). Based on this research, it can be concluded from the review of literature that the compensation strategy is highly linked with employee performance (EP). Several studies revealed that compensation, bonuses, and salary are crucial to improve the employee's performance. However, without these benefits, it can hinder the worker's performance development and professional growth. Furthermore, the compensation strategy can also improve ensure the employee's development and employee retention in the organization.

23 studies had analyzed the matter in further detail. The outcomes were a mixture of outcomes ranging from positive, negative, and moderate relationships. Among the 23 studies, only 15 studies had exhibited positive connections, seven studies had a negative relationship, and one with a moderate relationship. Thus, most of the studies concluded that compensation strategy can enhance the employee's performance and ensure that the employees are dedicated, loyal, and committed towards the organizations. This will portray equality and justice by all the workers in the organizations. This study summarized the compensation strategy have a positive effect on employee performance in Iraqi universities. The researcher suggestion the organization increase the compensation to employees because the higher compensation will improve the employee's performance in universities.

It is hopes that the outcomes from this study will significantly add greatly to the body of knowledge in this area by providing an insight on how to improve academic staff Performance. Also, this study will benefit the universities in Iraqi as well as the organizations. The knowledge and perception of the academics will be enhanced in understanding the impact of organizational justice on the association between compensation strategy and academic staff Performance to embark on further researches in the area. This study significantly serves as a source to the Iraqi Universities and Ministry of Education and even the organizations in terms of supportive policies that can reap better outcomes in high education Iraqi. 
INTERNATIONAL JOURNAL OF ACADEMIC RESEARCH IN BUSINESS AND SOCIAL SCIENCES

Vol. 10, No. 1, Jan, 2020, E-ISSN: 2222-6990 @ 2020 HRMARS

\section{Reference}

Azman, M. N. Bin., Shuraimi, F. Binti M., \& Yunus, M. Binti M. (2018). Enhancing English Language Learning and Teaching via Qgram (Telegram and Quizlet) Innovation. International Journal of Academic Research in Progressive Education and Development, 7(4), 435-446.

Adams, J. S. (1965). Inequity in social exchange. In Advances in experimental social psychology Vol. 2, 267-299.

Adeoye, A. O., \& Fields, Z. (2014). Compensation management and employee job satisfaction: A case of Nigeria. Journal of Social Sciences, 41(3), 345-352.

Aduda, J. (2011). The relationship between executive compensation and performance in the Kenyan banking sector. Journal of Accounting and Taxation, 3(6), 130-139.

Ahmad, S., \& Shahzad, K. (2011). HRM and employee performance: A case of university teachers of Azad Jammu and Kashmir (AJK) in Pakistan. African journal of business management, 5(13), 5249-5253

Ajzen, I., \& Fishbein, M. (2000). Attitudes and the attitude-behavior relation: Reasoned and automatic processes. European review of social psychology, 11(1), 1-33.

Al-Ameryeen, M. F. I. (2015). The effects of monetary, non-monetary and distributive fairness on employee performance: a study of the Phosphate Mines Co. Jordan (Doctoral dissertation, Universiti Utara Malaysia).

Alfandi, A. M., \& Alkahsawneh, M. S. (2014). The Role of the Incentives and Reward System in Enhancing Employee's Performance" A Case of Jordanian Travel and Tourism Institutions". International Journal of Academic Research in Business and Social Sciences, 4(4), 326.

Anitha, J. (2014). Determinants of employee engagement and their impact on employee performance. International journal of productivity and performance management, 63(3), 308.

Anwar, M. S., Aslam, M., \& Tariq, M. R. (2011). Temporary job and its impact on employee performance. Global Journal of Management and Business Research, 11(8),110-125.

Ashary, n. (2019). Analysis of the impact of workers' compensation and the environment on the performance of PDAM staff in Magetan Regency (PhD thesis, UMM).

Baeten, J. C., Basten, T., Basten, T., \& Reniers, M. A. (2010). Process algebra: equational theories of communicating processes,16(50), 70-93.

Bell, R., \& Martin, J. (2012). The relevance of scientific management and equity theory in everyday managerial communication situations. Journal of Management Policy and Practice, 13(3).

Boamah, R. (2014). The effect of motivation on employees' performance: empirical evidence from the BrongAhafo Education Directorate (Doctoral dissertation).

Brown, M. P., Sturman, M. C., \& Simmering, M. J. (2003). Compensation policy and organizational performance: The efficiency, operational, and financial implications of pay levels and pay structure. Academy of management Journal, 46(6), 752-762.

Collins, C. J., \& Clark, K. D. (2003). Strategic human resource practices, top management team social networks, and firm performance: The role of human resource practices in creating organizational competitive advantage. Academy of management Journal, 46(6), 740-751.

Darma, P. S., \& Supriyanto, A. S. (2017). The effect of compensation on satisfaction and employee performance. Management and Economics Journal (MEC-J), 1(1).

David, W. (2002).Compensation system. Journal of human resource,5(30), 23-24. 
Demerouti, E., Bakker, A. B., \& Leiter, M. (2014). Burnout and job performance: The moderating role of selection, optimization, and compensation strategies. Journal of occupational health psychology, 19(1), 96.

Denis, C., \& Michel, M. (2011). Fits in strategic human resource management and methodological challenge: Empirical evidence of influence of empowerment and compensation practices on human resource performance in Canadian firms. The International Journal of Human Resource Management, 20(4), 738-770.

DeNisi A. S., \& Griffins R. W. (2008). Human Resources Management. Houghton

Dremina, M. A., Davydova, N. N., \& Kopnov, V. A. (2016). Lifelong Learning in Russia: History, Concepts \& Practices. Multilingual Academic Journal of Education and Social Sciences, 4(2), 3046.

Feraro-Banta, L., \& Al Shaikh, S. (2017). Relation of Compensation and Benefits on Employees' Performance: A Study of Audit Firms in Bahrain. Relation, 4(5).

Furtado, F. (2015). Incentive Systems in Software Organizations, ICSEA 2009 - The Fourth International Conference on Software Engineering Advances. Porto, Portugal, 8(12),93-99.

George, O., Bamigbola, B. O., \&Akaighe, G.(2016). Effect of reward and compensation on employee loyalty and performance. In Asset Management Corporation Of Nigerian (AMCON).

Hameed, A., \& Waheed, A. (2011). Employee development and its affect on employee performance a conceptual framework. International journal of business and social science, 2(13),3-9.

Han, T. S., Chiang, H. H., \& Chang, A. (2010). Employee participation in decision making, psychological ownership and knowledge sharing: mediating role of organizational commitment in Taiwanese high-tech organizations. The International Journal of Human Resource Management, 21(12), 2218-2233.

Haryono, S. (2019). The Mediating Role Of Organizational Commitments On The Effects Of Work Discipline And Compensation On Employee Performance.

Hausman, C., Nebeker, A., McCreary, J., \& Donaldson, Jr, G. (2002). The worklife of the assistant principal. Journal of Educational Administration, 40(2), 136-157.

Ibrar, M., \& Khan, O. (2015). The impact of reward on employee performance (a case study of Malakand Private School). International letters of social and humanistic sciences, 52, 95-103.

Janssen, O. (2000). Job demands, perceptions of effort-reward fairness and innovative work behaviour. Journal of Occupational and organizational psychology, 73(3), 287-302.

Jean, K. N., Ngui, T. K., \& Robert, A. (2017). Effect of Compensation Strategies on Employee Performance: A Case Study of Mombasa Cement Limited. International Journal of Innovative Social Sciences \& Humanities Research 5(3):25-42

June, S., \& Mahmood, R. (2011). The relationship between role ambiguity, competency and personjob fit with the job performance of employees in the service sector SMEs in Malaysia. Business Management Dynamics, 1(2), 79-98.

Khan, R. A. G., khan, F. A., \& Khan, M. A. (2011). impact of training and development on organizational performance. global journal of management and business research, 11(7). 19-33.

Küster, I., \&Canales, P. (2011). Compensation and control sales policies, and sales performance: the field sales manager's points of view. Journal of Business \& Industrial Marketing, 26(4), 273-285. 
INTERNATIONAL JOURNAL OF ACADEMIC RESEARCH IN BUSINESS AND SOCIAL SCIENCES

Vol. 10, No. 1, Jan, 2020, E-ISSN: 2222-6990 @ 2020 HRMARS

Larbi, T. A. (2014). Effect Of Compensation Management On Employee Performance At The St. Michael's Catholic Hospital, Pramso. Department of Human Resource and Organizational Development.

Lawler, E.E. \& Worley, C.G. (2016). Winning support for organizational change: Designing employee reward systems that keep on working, Ivey Business Journal,15.

Mabaso, C. M., \& Dlamini, B. I. (2017). Impact of compensation and benefits on job satisfaction. Research Journal of Business Management, 11(2), 80-90.

Masea, I. N. (2016). Influence Of Compensation Practices On Performance Of Employees In The Saving And Credit Institutions In Nairobi City County (Doctoral Dissertation, School Of Business, University Of Nairobi).

Mayson, S., \& Barrett, R. (2016). Getting and keeping good staff: An analysis of human resource management "problems" in small firms. Report to CPA Australia, 23(4), 56-78

MaysounBaqer Mahdi.( 2015) Higher Education in Iraq His career and features developed by, the Journal of Educational and Psychological Research No. 47

Mcoliver, F. O. (2005). Management in nigeria: philosophy and practice. international journal of communication and humanistic studies, 2(1), 17-31.

Miffling Company. Boston New York

Moghimi, D., Zacher, H., Scheibe, S., \& Van Yperen, N. W. (2017). The selection, optimization, and compensation model in the work context: A systematic review and meta-analysis of two decades of research. Journal of Organizational Behavior, 38(2), 247-275.

Nchorbuno, D. A. (2011). The Role of Motivation on Employee Performance in the Public Sector: A Case Study of the University for Development Studies-Wa Campus (Doctoral dissertation).

Negash, R., Zewude, S., \&Megersa, R. (2014). The effect of compensation on employees motivation: In Jimma University academic staff. Basic Research Journal of Business Management and Accounts, 3(2), 17-27.

Njanja, R. K. (2013) Effect of Reward on Employee Performance: A Case of Kenya Power and Lighting Company Ltd., Nakuru, Kenya, International Journal of Business and Management; 8(21) 41-49.

Njoroge, S. W., \&Kwasira, J. (2015). Influence of compensation and reward on performance of employees at Nakuru County Government. IOSR Journal of Business and Management (IOSRJBM).

Nwokocha, I. (2016). Managing reward strategy to enhance employee performance, retention and productivity in organizations: A general overview. International Journal of Development and Management Review, 11(1), 20-38.

Obasan, K. A. (2012). Effect of compensation strategy on employees' performance: Evidence from Nigerian firms. Research Journal of Finance and Accounting, 3(7), 37-44.

Okeke, M. N., \&lkechukwu, I. A. (2019). Compensation Management and Employee Performance in Nigeria. International Journal of Academic Research in Business and Social Sciences, 9(2).

Osibanjo, A. O., Adeniji, A. A., Falola, H. O., \&Heirsmac, P. T. (2014). Compensation packages: a strategic tool for employees' performance and retention. Leonardo Journal of Sciences, 12 (25), 65-84.

Pradhan, R. K., \& Jena, L. K. (2017). Employee performance at workplace: conceptual model and empirical validation. Business Perspectives and Research, 5(1), 69-85. 
Pradita, M. Y. (2017). The impact of compensation, leadership style and characteristics of marketers on motivations and performance of marketers in Labor. Indonesian People's Bank (persero) tbk. Wave Branch. Journal of Business and Management, 4 (2).

Prasetya, A., \& Kato, M. (2011). The effect of financial and non-financial compensation to the employee performance. In The 2nd International Research Symposium in Service Management. Yogyakarta, Indonesia.

Premalatha, U. M. (2013). Impact of compensation system on employee performance-a study with special reference to service sector. international journal of management, it and engineering, 3(12), 32-42.

Peprah, W. K. (2018). Predictive Relationships among the Elements of the Fraud Diamond Theory: The Perspective of Accountants, International Journal of Academic Research in Accounting, Finance and Management Sciences 8 (3): 141-148.

Quartey, S. H., \& Attiogbe, E. J. (2013). Is there a link between compensation packages and job performance in the Ghana police service?. African Journal of Business Management, 7(44), 4398-4406.

Ramanathan, G. (2012). A study on human resource management practices and job satisfaction among bank employees in thanjavur district tamilnadu. 3(6), 63-85.

Ramli, A. H. (2019). Compensation, Job Satisfaction and Employee Performance In Health Services. Business and Entrepreneurial Review, 18(2), 177-186.

Rizal, M., Idrus, M. S., \&Djumahir, M. R. (2014). Effect of compensation on motivation, organizational commitment and employee performance (studies at local revenue management in Kendari city). International journal of business and management invention,3(2), 64-79.

Shahzadi, I., Javed, A., Pirzada, S. S., Nasreen, S., \&Khanam, F. (2014). Impact of employee motivation on employee performance. European Journal of Business and Management, 6(23), 159-166.

Shiah-Hou, S. R., \& Cheng, C. W. (2012). Outside director experience, compensation, and performance. Managerial Finance, 38(10), 914-938.

Spaans, M., Veen, V. D. M., \& Janssen-Jansen, L. (2010). The concept of non-financial compensation: What is it, which forms can be distinguished and what can it mean in spatial terms?. Planum: The European Journal of Planning, January, 5(22),12-18.

Stewart, E. B., Belcourt, M. S., Arthur, B. G., Snell, S. (2001). Essentials of Managing Human Resources.1st Canadian Edition.

Sudiardhita, K. I., Mukhtar, S., Hartono, B., Sariwulan, T., \& Nikensari, S. I. (2018). The Effect of Compensation, Motivation of Employee and Work Satisfaction to Employee Performance Pt. Bank Xyz (Persero) Tbk. Academy of Strategic Management Journal,16(12),33-45.

Tetteh-Annor, L. (2014). Effect of compensation management on employee performance at the St. Michael's Catholic Hospital, Pramso (Doctoral dissertation).

Tima, H. H., \& AK, U. M. S. W. (2011). Relationship between compensation systems and job perfromance among employees. Bachelor thesis, Universiti Malaysia Sarawak.

Tinaikar, S. (2017). Executive compensation disclosure and private control benefits: A comparison of US and Canadian dual class firms. Journal of International Accounting, Auditing and Taxation, 29, 32-51. 
Weibel, A., Rost, K., \&Osterloh, M. (2007). Crowding-out of intrinsic motivation-opening the black box.

Wucher, B., Martiny, P., Lani, F., Pardoen, T., Bailly, C., \& Dumas, D. (2017). Simulation-driven mold compensation strategy for composites: Experimental validation on a doubly-curved part. Composites Part A: Applied Science and Manufacturing,13(102), 96-107.

Yamoah, E. E. (2013). Relationship between compensation and employee productivity. Singaporean Journal of Business, Economics and Management Studies, 51(15),1-5. 